\title{
$\boldsymbol{U}$ rdimento
}

Revista de Estudos em Artes Cênicas E-ISSN: 2358.6958

\section{Contadores de histórias - um relato da criação de espaços a partir dos encontros com os Tikuna no Parque das Tribos}

Vanessa Benites Bordin

\section{Para citar este artigo:}

BORDIN, Vanessa Benites. Contadores de histórias um relato da criação de espaços a partir dos encontros com os Tikuna no Parque das Tribos. Urdimento, Florianópolis, v. 2, n. 38, ago./set. 2020.

DOI: http:/dx.doi.org/10.5965/14145731023820200027

Este artigo passou pelo Plagiarism Detection Software | iThenticate 
Contadores de histórias - um relato da criação de espaços a partir dos encontros com os Tikuna no Parque das Tribos

Vanessa Benites Bordin ${ }^{1}$

\begin{abstract}
Resumo
Este artigo se propõe a fazer uma reflexão sobre a pesquisa realizada no campo das práticas pedagógicas e experiências poéticas vividas junto aos indígenas da etnia Tikuna. Esses encontros sensíveis se pautaram pela busca de diálogo com os saberes ameríndios e a criação de um espaço de conhecimento e de trocas culturais que potencializa as vozes dos sujeitos envolvidos - os indígenas, os alunosperformers e a performer-professora. Encontros com outros corpos, de pessoas, de grupos, de experiências, de lugares, de ideias, de histórias, de culturas, de etnias e de gênero, constituindo a malha de colaborações. Esses encontros falam da experiência com a comunidade indígena Parque das Tribos localizada no perímetro urbano da cidade de Manaus, Amazonas, em que o foco está na relação de troca junto à professora Tikuna Mepaeruna e as crianças Tikuna no Espaço Cultural Uka Umbuesara Wakenai Anumarehit, assessorado pela Gerência de Educação Escolar Indígena (GEEI/SEMED) instituído dentro da comunidade.
\end{abstract}

Palavras-chave: Encontros. Narração de histórias. Prática artístico-pedagógica. Saberes ameríndios.

Storytellers - an account of the creation of spaces from the encounters with the Tikuna in the Parque das Tribos

\begin{abstract}
This article proposes to reflect on the research carried out in the field of pedagogical practices and poetic experiences lived with the indigenous people of the Tikuna ethnic group. These sensitive meetings were guided by the search for dialogue with Amerindian knowledge and the creation of a space of knowledge and cultural exchanges that potentiates the voices of the subjects involved - the indigenous people, the student-performers and the performer-teacher. Meetings with other bodies, people, groups, experiences, places, ideas, stories, cultures, ethnicities and gender, constituting the network of collaborations. These meetings speak about the experience with the indigenous community Parque das Tribos located in the urban perimeter of the city of Manaus, Amazonas, where the focus is on the exchange relationship with teacher Tikuna Mepaeruna and the Tikuna children at the Uka Umbuesara Wakenai Anumarehit Cultural Space, assisted by the Indigenous School Education Management (GEEI / SEMED) established within the community.
\end{abstract}

Keywords: Meetings. Storytelling. Artistic-pedagogical practice. Amerindian knowledge.

Professora Doutora Adjunta do Curso de Teatro da Universidade do Estado do Estado do Amazonas. Doutora em Artes Cênicas, Escola de Comunicação e Artes, da Universidade de São Paulo (ECA/USP). Integrante do grupo de pesquisa Tabihuni/CNPQ. vavabb@hotmail.com 


\title{
As árvores do Eware
}

\begin{abstract}
Eware é a nossa terra
é o começo do mundo,

onde foi criado o povo Ticuna.

Nesse lugar corre o igarapé que também se chama Eware.

Das águas do Eware nosso deus Yoi nos pescou.

Eware, tuas árvores e tuas águas

são nossa herança.

Os velhos contam que as árvores do Eware são diferentes.

A mata é baixa, nunca cresce e nunca morre.

Tem muita sorva, buriti, açaí, ingá, cupuí, araça, bacaba, bacuri, mapati, sapota, pamá

Também tem muitas flores.

Essa vegetação do Eware se chama bunecü,

Porque é sempre pequena e nova como uma criança, bue.

O Eware é protegido por animais e gente encantada.

De cada lado do igarapé ainda estão a casa do Yoi e de Ipi, Assim como antigamente. Também está o caniço que os irmãos usaram para pescar os animais e as pessoas. ${ }^{2}$

"O Eware é nossa terra sagrada, é lá que vivem os encantados.”

Para que o espaço seja habitável e representável, para que possamos nos situar, nos inscrever nele, ele deve contar histórias, ter toda uma espessura simbólica, imaginária. Sem narrativas - nem que seja uma mitologia familiar, umas poucas lembranças - o mundo permaneceria lá como está, indiferenciado; ele não nos seria de nenhuma ajuda para habitar os lugares em que vivemos e construir nossa morada interior. (Petit, 2019, p. 19-20).
\end{abstract}

O desejo em conhecer o universo ameríndio se deu quando me vi diante de uma cultura completamente diferente da minha, ao deixar o interior do Rio Grande do Sul para viver em Manaus4. Apesar de vir de uma terra de indígenas Guaranis ${ }^{5}$,

\footnotetext{
${ }^{2}$ Retirado de: O Livro das Árvores: Organização Geral dos Professores Tikuna Bilíngues. Impressão: Gráfica e editora Brasil Ltda. Benjamin Constant, AM, Brasil, 1998, p. 22-23.

${ }^{3}$ Mepaeruna. Os Tikuna chamam de encantados, que seriam seres imortais, ou, espíritos.

${ }^{4}$ Quando assumi o cargo de professora efetiva no Curso de Teatro (bacharelado e licenciatura) da Escola de Artes e Turismo (ESAT) na Universidade do Estado do Amazonas (UEA).

${ }^{5}$ Santo Ângelo da Missões, Rio Grande do Sul.
} 
o Rio Grande do Sul não é especialmente lembrado como um território indígena ${ }^{6}$, ao contrário do Amazonas que é o estado com o maior número de indígenas de diferentes etnias do Brasil.

Em Manaus, identifiquei a forte presença da cultura ameríndia, e logo que cheguei tive a oportunidade de conhecer o interior do Amazonas onde essa característica se evidencia?. Ao perceber que estava cercada por indígenas, de muitas etnias, em um território que pertence a eles, senti que precisava, e como era urgente conhecê-los para entender o contexto em que eu estava me inserindo, conhecer aquele lugar, aquelas pessoas, sua história.

Não tinha como me eximir disso, era impossível negar a nova realidade com a qual eu me deparava. Eu não poderia trabalhar artisticamente e pedagogicamente com aquelas pessoas desconhecendo sua realidade. Como eu iria propor metodologias de criação sem saber com quem eu estava atuando? E, ainda, reconhecendo que minha realidade era outra. O mais importante entre as diferenças passa pela nossa concepção de arte, sem similar no mundo ameríndio.

Enquanto aprendiz de minha experiência, de minha corporeidade, reflito sobre os caminhos que constituem o processo de formação do performer e do professor, criando e desenvolvendo suas experiências poéticas em contextos que podem ser diferentes do seu, possuindo complexidades que vão além de seu entendimento. Contudo, primando pela sensibilidade em distinguir a singularidade de cada sujeito com quem atuam, percebendo que existem outros modos de se constituir no mundo, valorizando a multiplicidade de conhecimentos e as diferentes formas de saberes.

Nesta direção, trabalhamos nossos corpos em relação aos outros corpos, estimulando-nos a construir uma trajetória de descoberta pessoal onde nossos desejos, nossos anseios, nossa voz, estejam em diálogo com os desejos, os anseios, as necessidades e as vozes do coletivo em que estamos inseridos.

${ }^{6}$ O Rio Grande do Sul é frequentemente lembrado como a terra dos colonizadores alemães e italianos.

No ano de 2014, quando fui jurada de quatro festivais folclóricos da Festa do Boi-Bumbá, um em Manaus e três em diferentes cidades do interior do Amazonas. 
A antropóloga Michèle Petit (2019) nos fala que a criação de espaços habitáveis pelo ser humano, em diferentes contextos, se dá pela transmissão cultural que permite por meio de narrativas, que podem ser mitológicas, ou, histórias familiares, elaborar a percepção do mundo, alimentando o pensamento, tornando os espaços não só lugares de passagem, mas lugares de permanência onde se constroem laços de afetividade, então, os espaços já não são somente físicos, mas espaços de afetos e histórias que perpetuam tradições e saberes.

\section{Conhecendo os Tikuna ${ }^{8}$}

Para ampliar meu campo de pesquisa fui em busca de teorias que pudessem me ajudar a entender o universo ameríndio - com cuidado - sem apropriações e deslumbre. Comecei a disciplina de pós-graduação em Antropologia na Universidade Federal do Amazonas, intitulada "Arte e Xamanismo na Antropologia", ministrada pela professora doutora Deise Lucy Montardo, no primeiro semestre de 2015. Em uma das aulas demonstrei meu interesse em realizar uma pesquisa nesse sentido, foi então, que minha colega na época, a pesquisadora Silvana Teixeira, que trabalha com os Tikuna, me falou sobre o ritual de iniciação feminina Worecü, A Festa da Moça Nova, principal ritual do povo Tikuna que acontece quando a moça Tikuna tem sua menarca ${ }^{9}$. Consequentemente, por meio desta indicação, busquei referências e descobri um universo de máscaras presentes no ritual que me fascinaram, principalmente por suas características que em um primeiro momento relacionei ao universo dos bufões, minha pesquisa acadêmica anterior.

As teorias ajudam a compreender como se engendra o pensamento ameríndio e suas particularidades, que se delineia diferente da minha forma de pensar $^{10}$, mas foi a convivência diária, os encontros, as conversas sinceras, a

8 Tikuna, Ticuna, Tucuna é algumas das grafias desse povo ameríndio que se encontra na região Amazônica de tríplice fronteira entre Brasil, Colômbia e Peru. Utilizo a grafia com K (Tikuna) pois os Tikuna com quem convivo escrevem assim.

9 Primeira menstruação.

${ }^{10}$ Que sou fruto da cultura ocidental dominante - branca, europeia, cristã.... 
participação nas atividades do dia a dia, que servem como dados etnográficos, que entrecruzados às teorias possibilitaram a reflexão e a compreensão das ideias apresentadas aqui.

Aqui trago a experiência de convívio com os indígenas onde criamos um espaço de troca de conhecimento a partir de experiências poéticas. Nesse sentido, falar sobre a cultura ameríndia - diante da atual ameaça aos povos indígenas em prol do progresso, no contexto político em que estamos vivendo onde tantos direitos alcançados e valores construídos estão sendo colocados em xeque e questionados - pautando o reconhecimento de sua língua e sua cultura que formam sua identidade não é querer distanciá-los de nossa sociedade, ao contrário, é acreditar, que os que assim quiserem, possam viver à sua maneira pertencendo a essa sociedade, sem serem marginalizados por isso. As comunidades indígenas nos mostram que outra forma de vida é possível, para além do nosso sistema capitalista individualista, com valores pautados em ações coletivas.

A reflexão se apresenta como consequência do meu olhar de artista e o quanto a experiência no espaço indígena afeta, renova e metamorfoseia meus processos de criação fruto do diálogo que estabeleço com suas variadas formas de saberes.

A relação que os indígenas têm com o tempo é completamente diferente da minha, que vivo (penso) dentro de um modelo de sociedade capitalista, que me deixa ansiosa, onde executo várias atividades ao mesmo tempo. Tenho a sensação de que por estarmos inseridos nesse tempo capitalista, somos impulsionados a correr e desempenhar diferentes tarefas para competir em igualdade. Cria-se uma espécie de doença que nos acomete e faz com que se perca a própria noção do tempo, ocasionando dificuldade em nos colocarmos no tempo presente. O que percebo diferente nos indígenas, já que a forma como vivem, como se relacionam no mundo não se encaixa dentro desse sistema, consequentemente sua relação com o tempo é outra, reflexo de seu modo de vida comunitário. Uma relação especialmente ligada aos ciclos naturais da vida, é o tempo da 'coisa acontecer', o tempo da planta crescer, do fruto amadurecer, da chuva cair ou cessar, da 
maqueira ${ }^{11}$ ficar pronta, do peixe moquear ${ }^{12}$. Tudo isso faz com que percebam que o tempo não pode ser controlado.

O estudo sobre o universo Tikuna fez com que eu buscasse conhecer esse povo. O primeiro encontro com os Tikuna foi na aldeia Nossa Senhora de Nazaré no município de São Paulo de Olivença, Amazonas, lá convivi o dia-a-dia no espaço da comunidade e posteriormente voltei para vivenciar o ritual Worecü. Mas achava que além disso precisava me envolver mais com os Tikuna, assim, queria conhecer os Tikuna de Manaus, já que o fato de os indígenas estarem cada vez mais inseridos em contexto urbano é uma realidade crescente. Foi então, que conheci Mepaeruna, da etnia Tikuna, cantora e artesã que vive no Parque das Tribos, comunidade indígena situada no perímetro urbano de Manaus, onde moram famílias de cerca de vinte e quatro etnias indígenas. Hoje, acompanho a luta desses povos para manter as características fundamentais de seus modos de vida, preservando aspectos vitais de sua cultura, especialmente relacionados à sua língua.

Mepaeruna é uma das mulheres do Parque das Tribos com quem mais convivo, temos uma relação que já é de amizade, para além do trabalho e pesquisa. Percebo seu empenho para que os saberes tradicionais de seu povo sejam mantidos na comunidade, começando por sua casa. Ela me contou que logo que saiu da aldeia ${ }^{13}$ morava em um bairro de Manaus onde não tinha espaço para as crianças brincarem e nem contato com outros indígenas. Não podia plantar e nem fazer peixe, "só comia frango do mercado", por isso decidiu tentar um pedaço de terra no Parque das Tribos, agora lá, ela pode manter seus costumes, fazer peixe para os filhos, plantar banana, macaxeira e principalmente falar sua língua. Mepaeruna faz questão de só falar na língua Tikuna com os seus filhos, que aprendem o português no convívio com os não-indígenas.

Mepaeruna achou que seria interessante levarmos para a comunidade Parque

11 Espécie de rede para deitar-se.

12 Para conservar o peixe eles o deixam secando na fumaça da brasa, seria como um peixe defumado, que se conserva por mais tempo.

${ }^{13}$ Comunidade de Porto Cordeirinho, município de Benjamin Constant, Amazonas. 
das Tribos o trabalho que desenvolvo na UEA em um projeto de extensão que envolve a contação de histórias com o teatro de formas animadas: "Contadores de histórias: o teatro de formas animadas na comunidade", ao lado dos estudantes dos cursos de licenciatura e bacharelado em Teatro. Para ela, que estava trabalhando como professora voluntária no Espaço Cultural de Educação Indígena Uka Umbuesara Wakenai Anumarehit, o engajamento de parceiros que contribuam dentro da comunidade é fundamental para que possam seguir desenvolvendo suas atividades.

O projeto desenvolvido é parte de um projeto coletivo ${ }^{14}$ de produtividade acadêmica intitulado: "Encontro das águas: projeto de Teatro, Música e Comunidade", que une pesquisa, ensino e extensão com o intuito de tornar fluido o processo de ensino-aprendizagem dos estudantes, bem como as experiências poéticas desenvolvidas na comunidade, partindo da vivência de troca entre universidade e comunidade.

Além de considerar as experiências poéticas desenvolvidas no contexto da comunidade, nos propomos a refletir sobre a sua realidade, ou seja, com a prática de contar histórias contemplar as experiências acumuladas pelos diferentes sujeitos, refletindo sobre as possíveis contribuições que as práticas performativas podem oferecer ao ampliar as percepções estéticas e sensíveis, aproximando crianças, jovens, adultos e idosos. Assim, buscamos a construção de pesquisas que venham contribuir no processo de formação de profissionais preparados para desenvolver ações artísticas e educacionais interventivas, com soluções criativas para as problemáticas apresentadas no contexto da comunidade, dispondo de conhecimentos e experiências que os auxiliem no desenvolvimento de suas práticas profissionais, aptos para enfrentar os desafios da vida cotidiana.

Temos constatado que ao articular o conhecimento acadêmico engendrado aos saberes da comunidade é possível proporcionar a construção de novas experiências estéticas significativas para todos os participantes. Existem alguns

14 Projeto em parceria com mais dois professores da ESAT-UEA, o professor doutor Bernardo Mesquita do Curso de Música e a professora mestra Amanda Aguiar Ayres do Curso de Teatro. 
núcleos de pesquisas em diferentes comunidades periféricas ${ }^{15}$ de Manaus que se fortalecem enquanto um coletivo maior que chamamos de "Arte e Comunidade", formando multiplicadores dentro das próprias comunidades, visando a autonomia dos envolvidos para a realização das atividades.

Com os "Contadores de histórias: o teatro de formas animadas na comunidade" atuamos com crianças e jovens experimentando a contação de histórias enquanto performance, que é tecida por práticas como a improvisação e o teatro de formas animadas, tendo como temática a especificidade cultural de cada comunidade no contexto amazônico, buscando contribuir naquilo que desejam manifestar.

É constante a reflexão do coletivo que faz parte do projeto sobre como trabalhar com a comunidade - que vai se fortalecendo com a prática - juntos na construção de um caminho que está se delineando amparado por teorias e experimentações.

Estamos atuando com as crianças e os jovens no intuito de fortalecer o que eles já têm enquanto potencial poético, que vêm de sua maneira de se colocar e agir no mundo, característica de seu modo de vida ameríndio, fortalecendo o que está sendo desenvolvido pelas professoras indígenas. Ainda não temos a intenção de realizar uma obra artística, mas sim, experimentar processos de criação sem a

15 Iniciamos com a comunidade Colônia Antônio Aleixo, zona leste de Manaus. Um bairro que ainda hoje é visto com preconceito devido à sua história. Afastado do centro da cidade, era o bairro para onde antigamente (década de 1940) eram mandadas as pessoas com hanseníase. Deste modo, o local ficou estigmatizado como um leprosário, evitado pelas pessoas da cidade e sem receber a devida infraestrutura que deveria ser oferecida pelos órgãos públicos. Alguns dos idosos do bairro são sobreviventes daquele tempo, muitos portadores da doença, mas hoje em dia o bairro não tem mais essa função. No entanto, por ser um bairro periférico, desprovido de infraestrutura e carregar esse estigma, muitos que moram lá têm dificuldade em arrumar emprego, entre uma série de outros fatores que que essa carga histórica desencadeia. Hoje quem toma conta das ações no bairro são alguns alunos que já se formaram em Teatro na UEA, ao lado de outros estudantes em formação. Ainda contamos com Dona Socorro, uma multiplicadora da própria comunidade, que foi parceira do projeto desde o início, acompanhando as crianças até a Universidade e nos recebendo na comunidade. Dona Socorro aprendeu a fazer bonecos e máscaras e hoje trabalha com as crianças e adolescentes de forma autônoma em um espaço dentro da comunidade, o Instituto Ler para Crescer, um dos parceiros do projeto. Outra comunidade em que atuamos é no Quilombo Urbano de São Benedito, onde a cultura afro se faz presente, principalmente na figura das crioulas que movimentam diferentes ações em prol da comunidade. Começamos ações no PROSAMIM (Programa Social e Ambiental dos Igarapés de Manaus) com habitações populares, na zona sul, próximo a ESAT (Escola de Artes e Turismo) da UEA que é onde o curso de Teatro funciona. Quem está mais focada no trabalho com o PROSAMIM é o grupo coordenado pela professora Amanda Aguiar Ayres, que foi até o espaço por ser uma comunidade próxima a ESAT-UEA e ainda não havíamos nos integrado a ela. Por fim, mais recentemente - desde agosto de 2017 - estamos na comunidade indígena Parque das Tribos, sendo o coletivo que atua nesse espaço coordenado por esta pesquisadora. 
preocupação com um produto final.

Nossas experiências poéticas ao lado de Mepaeruna, sempre atentam para os acontecimentos e problemáticas que fazem parte do dia a dia da comunidade. A maioria das crianças participantes do projeto são da etnia Tikuna, mas crianças de outras etnias frequentam as aulas.

Mepaeruna é a figura central dessa experiência, ela representa a cultura Tikuna viva nesse espaço citadino, é ela quem cuida para que sua língua e costumes sejam preservados dentro de sua casa, e busca difundi-los para além do ambiente familiar, atuando como professora voluntária no Espaço Cultural Uka Umbuesara Wakenai Anumarehit, trabalhando com artesanato e grafismos em eventos na cidade de Manaus e no interior do Amazonas, e também fazendo o que mais gosta que é cantar as canções de seu povo.

O nome de Mepaeruna significa "o galho bonito onde pousa o japó” e se refere a sua nação, ou clã̄ ${ }^{16}$ que é japó, um pássaro muito comum na região amazônica.

Todos os nomes dos Tikuna são escolhidos a partir de seus clãs ou nações. “Essas nações regulam os casamentos, a organização social e política” (Costa, 2015, p. 53). Deste modo, os Tikuna se dividem em duas nações: os com plumas (que são representados por aves como: arara, gavião, mutum, japó, etc.) e os sem plumas (que são animais terrestres e vegetais: onça, avaĺ, jiboia, saúva, buriti, jenipapo). O que define o casamento é a nação, sendo que os com plumas só podem se casar com os sem plumas. E quem define a nação é o pai, por exemplo, se uma mulher da nação de japó tem um filho com um homem da nação de onça, o seu filho será onça. "Se casa errado os filhos nascem com defeito e aparece ngo'o (bicho) do mato para levar". Os que pertencem a mesma nação são considerados primos.

Cada nação tem um grafismo para o rosto e para o corpo, tem o feminino e o masculino, esses grafismos são pinturas corporais que fortalecem a relação da pessoa com o símbolo de sua nação. Para entrar no ritual Tikuna de iniciação

16 Um grupo de pessoas descendentes de um ancestral mítico, ou seja, do qual não é possível demonstrar uma conexão genealógica. (Matarezio Filho, 2015, p. 41). 
feminina, Worecü, ou, A Festa da Moça Nova, todos têm que fazer a pintura com o sumo de jenipapo relacionada à sua nação para se identificarem. Mepaeruna disse que "é como se fosse sua carteira de identidade", evitando o risco de se apaixonar por alguém errado.

\section{Buetica - A árvore da vida}

A samaumeira que cobria o universo

No princípio, estava tudo escuro, sempre frio e sempre noite. Uma enorme samaumeira, wotchine, fechava o mundo, e por isso não entrava claridade na terra. Yoi e Ipi ficaram preocupados. Tinham que fazer alguma coisa. Pegaram um caroço de arara-tucupi, tcha, e atiraram na árvore para ver se existia luz do outro lado. Através de um buraquinho, os irmãos enxergaram uma preguiça-real que prendia lá no céu os galhos da samaumeira. Jogaram muitos e muitos caroços e assim criaram as estrelas. Mas ainda não havia claridade. Yoi e Ipi ficaram pensando e decidiram convidar todos os animais da mata para ajudarem a derrubar a árvore. Mas nenhum deles conseguiu, nem o pica-pau. Resolveram, então, oferecer a irmã Aicüna em casamento para quem jogasse formigas-de-fogo nos olhos da preguiça-real. O quatipuru tentou, mas voltou no meio do caminho. Finalmente aquele quatipuruzinho bem pequeno, taine, conseguiu subir. Jogou as formigas e a preguiça soltou o céu. A árvore caiu e a luz apareceu. Taine casouse com Aicüna. ${ }^{17}$

${ }^{17}$ Retirado de: O Livro das Árvores, 1998, p. 14. 
Figura 1 - Mepaeruna contando a história da samaumeira que cobria o universo. Espaço Cultural Uka Umbuesara Wakenai Anumarehit. Parque das Tribos, Tarumã, Manaus (AM)

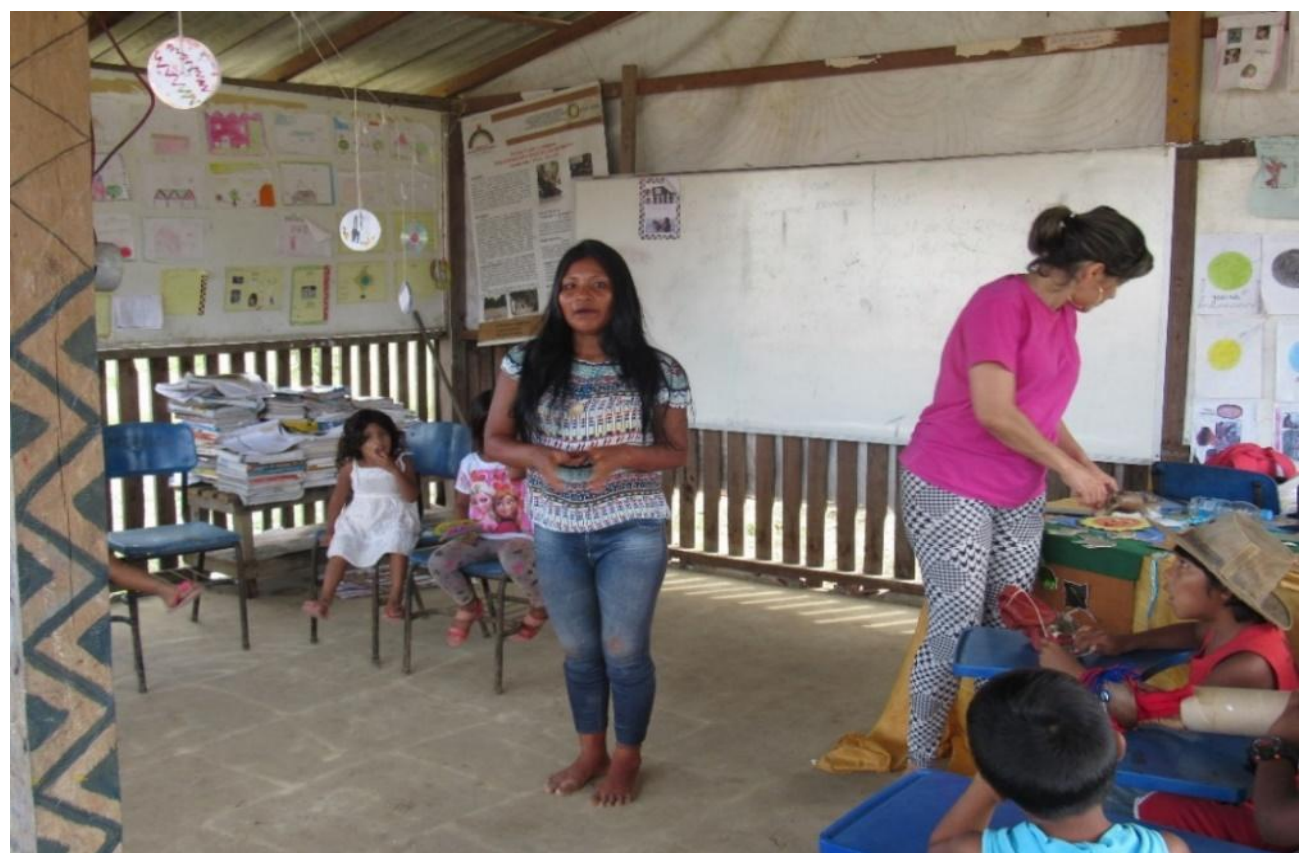

Foto: arquivo pessoal da pesquisadora, 24 maio 2018

Esta história sobre o surgimento da luz para os Tikuna foi contada por Mepaeruna em nosso primeiro encontro com o grupo de crianças indígenas no Espaço Cultural Uka Umbuesara Wakenai Anumarehit. Como estou envolvida com os Tikuna desde 2015, já conhecia essa história. Mepaeruna contou do seu jeito, trago aqui a versão do Livro das Árvores Tikuna, que foi a que utilizamos para a prática de improvisação com as crianças, sugerido pela própria Mepaeruna. Nesse livro, produzido por professores Tikuna, encontramos várias histórias de seu povo escritas em uma linguagem acessível para crianças.

Queríamos um nome para o nosso grupo focado nos saberes Tikuna, pensamos em algo que remetesse a acolhimento, aconchego, por causa das crianças e das mães. Eu, Mepaeruna e os estudantes participantes do projeto falamos sobre vários possíveis nomes, até que por fim, Mepaeruna sugeriu chamar de buetica, que é o lugar onde a criança fica guardada no útero da mãe, seria o que chamamos de placenta, que é conhecida também como a árvore da vida por seu formato cheio de ramificações e ser o órgão que exerce todas as funções que 
mantém o bebê vivo. Como as histórias do universo Tikuna traziam muitas imagens da natureza, especialmente relacionada às árvores, a metáfora da árvore da vida foi significativa naquele contexto.

Quando iniciei a parceria com Mepaeruna já conhecia muitas histórias e canções Tikuna da convivência na aldeia. Quanto mais vivenciamos o dia a dia na comunidade, mais compreendemos o universo que envolve os ensinamentos trazidos pelas canções e histórias do mundo ameríndio que são recheados de metáforas. Falo aqui em metáforas a partir do estudo de Els Lagrou (2007, p. 139) onde ela vai dizer que:

Se se considerasse a metáfora como uma figura de linguagem figurativa que só representa e não presentifica, este instrumento da linguagem pertenceria antes a lógica relativista ocidental do que a lógica transformacionista ameríndia. Entretanto, a abordagem da metáfora que proponho aqui leva em conta o valor agencial tanto do ponto de vista da ação quanto da fala, a fala através de metáforas, onde estas ações sobre o mundo (ou os mundos interconectados dos diferentes seres e estados de ser) ajudam a fazê-lo(s) em termos bem concretos, moldando-o(s) e transformando-o(s).

Deste modo, Els Lagrou (2007) diz que toda linguagem é metafórica e polissêmica na medida em que confere significado à experiência, associando imagens que não se relacionam de antemão, mas geram novas perspectivas, o que é essencial para o processo cognitivo que precisa de vias criativas para compreender as relações entre as realidades que desconhece e as que conhece, elaborando percepções e experiências novas. Portanto, as metáforas são usadas para conectar mundos diferentes gerando um mundo novo por meio da interação de perspectivas. Podem existir muitos mundos exteriores, mas, o mundo onde vivemos é aquele que faz sentido para nós a partir do que experimentamos, percebemos e imaginamos.

A criatividade poética intrínseca a elaboração do universo metafórico, que permeia as canções e histórias ameríndias, contribui no processo de ensinoaprendizagem a partir da perspectiva do olhar sensível que as experiências poéticas proporcionam. O uso da metáfora muda nosso conhecimento e percepção do mundo, fazendo com que nossa visão de mundo se transforme. 
Esse universo metafórico aproxima crianças, jovens e adultos, pois se torna uma linguagem acessível que permite diferentes interpretações a partir da vivência de cada um, o que enriquece as práticas performativas com a contação de histórias realizadas no contexto da comunidade.

\section{Contando e cantando histórias vamos tecendo o nosso espaço de criação ${ }^{18}$}

Nesse primeiro encontro com as crianças do grupo de Mepaeruna, algumas mães estavam presentes acompanhando seus filhos. Após Mepaeruna contar a história fizemos uma roda e nos apresentamos com um jogo em que cada uma falava seu nome fazendo um movimento que ajudasse nessa apresentação, em seguida, todos na roda repetiam o nome e o movimento realizado. As mães estavam muito desinibidas, mais do que as crianças, e isso contribuía para que as crianças realizassem a atividade. Levamos bonecos, as crianças ficaram curiosas, queriam pegá-los, me chamou atenção um dos meninos desenhando grafismos indígenas no suporte do boneco. O universo dos grafismos é muito valorizado pelos indígenas, as crianças desde pequenas veem seus parentes desenhar e começam a praticar o desenho dos grafismos em seus corpos e objetos diversificados.

Antes de finalizarmos o encontro, uma das meninas pediu para cantar uma canção na língua da etnia ameríndia a que pertence, que é a Baré, ela cantou e repetiu algumas vezes a canção até que todos cantassem juntos. Cantando juntos em roda, a dança veio naturalmente, uma dança circular com uma pisada marcada no centro da roda, que no Parque das Tribos é muito frequente em diversos eventos que realizam.

Fechamos o encontro com todos de mãos dadas e cada um falou uma palavra que descrevesse a experiência do dia. Palavras como: "amizade",

18 Para os Tikuna os mitos e as canções, como me disseram, "trazem ensinamentos", toda canção conta uma história e a palavra Tchiga utilizam para se referir à narração, história, canção, notícia, relato, ligado a entidades míticas ou não. 
"grafismo", "bonecos", “história”, “união", “amor”, foram mencionadas. Compartilhamos o lanche com a contribuição de algumas mães e conversamos sobre assuntos diversos.

Figura 2 - As mães improvisando no Espaço Cultural Uka Umbuesara Wakenai Aunumarehit
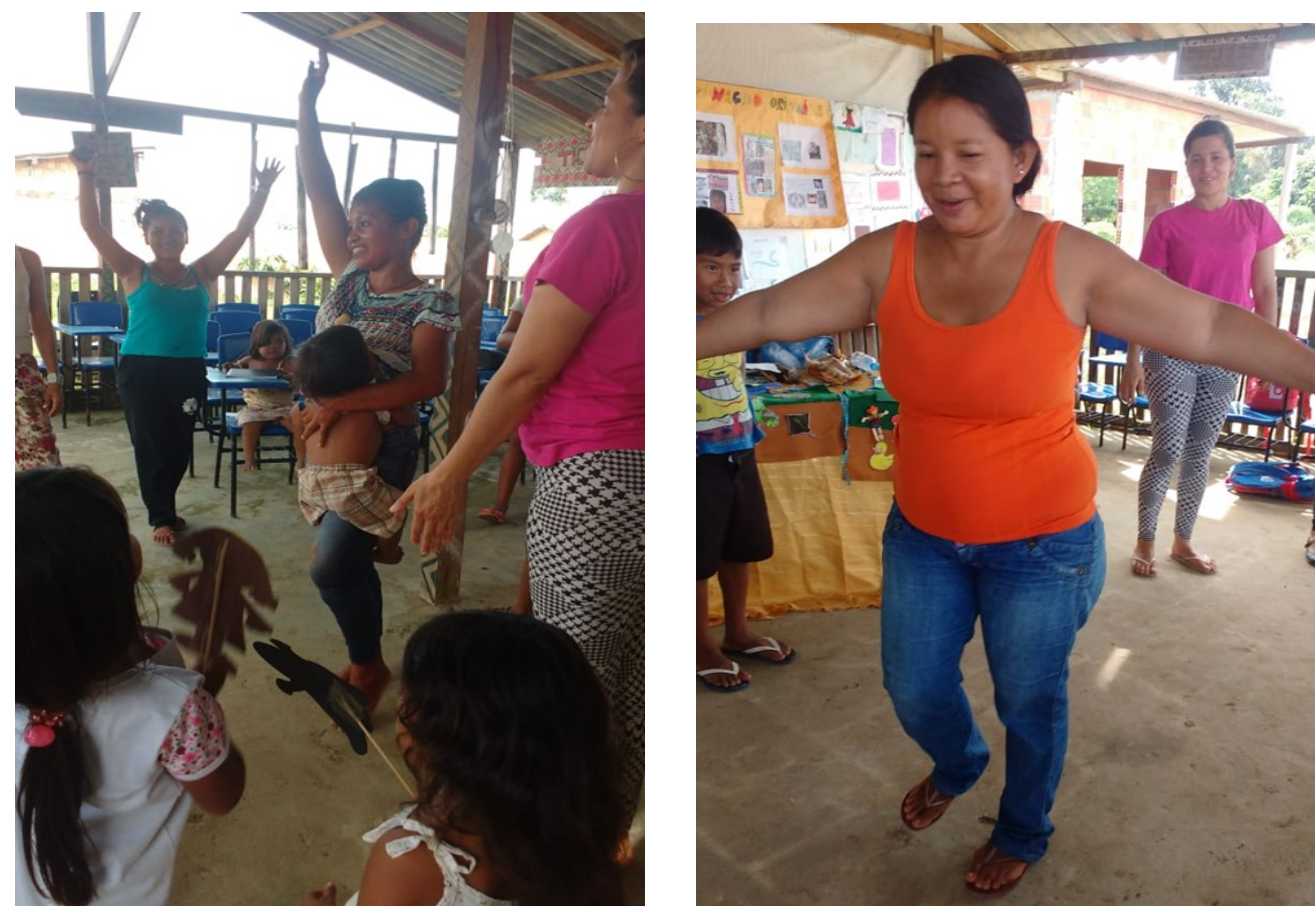

Foto: Arquivo pessoal da pesquisadora, 24 maio 2018

Essas proposições que levamos para as aulas são sempre pensando na criação de um espaço lúdico, que remeta ao brincar, para que o aprendizado seja prazeroso e acessível.

Falar em brincar nesse contexto educacional requer certo cuidado, pois pode levar a interpretações equivocadas. É sempre importante atentarmos para que a brincadeira seja incentivada de forma saudável, como uma atividade coletiva, mas respeitando a individualidade de cada criança, já que o brincar é uma expressão natural da vida da criança, é a forma como se manifesta no mundo e desenvolve sua potência criativa. Portanto, é fundamental que tenhamos um olhar sensível sobre esse universo criado por ela, que é muito íntimo.

Retomo a antropóloga Michèle Petit (2019) que estuda a questão da 
transmissão oral e da leitura em diferentes contextos culturais (inclusive indígenas brasileiros como os Tikuna), trazendo a ideia do brincar próximo da arte, que faz parte da condição humana como forma de se expressar no mundo:

O universo humano seria uma composição de diversos mundos que se construiriam de maneira paralela e interativa. O da ficção pertence ao universo mais geral do jogo, da brincadeira, e exerce uma função vital. Ele participa do trabalho permanente de modelização de nossas relações, da exploração de nossa complexidade interativa, e está implicado na formação e na aprendizagem sob diferentes formas: a do faz de conta, mais a do jogo simbólico que se inscreve em seu prolongamento, no qual a criança faz um "teatro", e a da ficção narrativa que dá lugar a múltiplas interpretações. (Petit, 2019, p.141).

Para complementar essa referência podemos pensar o brincar a partir dos estudos dos autores Nelson Piletti, Solange Marques Rossato e Giovani Rossato (2014) que abordam cada fase da psicologia do desenvolvimento humano vendo a brincadeira como uma preparação de "transição para a atividade do estudo que se constitui numa nova etapa de desenvolvimento" (Piletti, Rossato e Rossato, 2014, p. 137). Portanto, a criança expressa através da brincadeira sua percepção do mundo, dos objetos humanos e se desenvolve psicologicamente.

Os autores apontam o jogo de faz de conta da criança como um processo de dramatização da vida para entendê-la, contribuindo na expansão da memória, do pensamento, da imaginação, da atenção e da linguagem oral. Imitando e brincando a criança aprende novos papéis e se desenvolve: "A criança experimenta, portanto, modificações qualitativas no desenvolvimento cognitivo." (Piletti, Rossato e Rossato, 2014, p. 138).

Em nossas experimentações no Parque das Tribos o brincar está ligado às ações de contar e cantar histórias através da improvisação. Enquanto atriz percebo a improvisação como um ato de "brincar", pois quando estou a exercê-la minha imaginação libera meu corpo de uma forma que me coloco disponível no espaço de criação diferente do cotidiano, trazendo à tona ações, gestos, sons, palavras de forma espontânea ${ }^{19}$ e poética. Essa característica da espontaneidade, muito 
trabalhada durante a prática da improvisação, eu relaciono ao universo do brincar e ao universo ameríndio, pois percebo na convivência com os indígenas o que chamaríamos de $\operatorname{arte}^{20}$ presente em sua vida cotidiana.

Na lógica ameríndia as fronteiras entre vida e arte não se definem de forma tão categórica, as coisas fluem de maneira mais orgânica, mesmo que existam objetos para serem utilizados e objetos para serem contemplados, eles possuem um significado de existência e relação com o ciclo da vida para as pessoas daquele povo, através de práticas que ritualizam sua existência.

Como disse anteriormente, a característica da espontaneidade é algo que relaciono ao brincar e a improvisação, e que percebo muito presente nas ações do mundo ameríndio. Isso ficou evidente desde nosso primeiro encontro com as crianças indígenas no Parque das Tribos. Enquanto a professora indígena finalizava a aula, colocamos alguns instrumentos musicais em cima da mesa para mais tarde propormos algo com eles, e o que foi mágico foi o fato de não precisarmos falar absolutamente nada, só colocamos os instrumentos musicais ali e as crianças e os jovens começaram a improvisar, cantando e tocando músicas indígenas com os tambores e os chocalhos. Espontaneamente foram para o chão e fizeram uma roda com todos interagindo como se fosse uma brincadeira, "sem bagunça", bem organizados e com respeito.

Faz quinze anos que trabalho com crianças e jovens, e, por mais espontâneos que sejam, quando é o primeiro encontro e eles ainda não sabem como vai se desenvolver, esperam um comando para iniciar, nunca havia acontecido de tomarem a iniciativa e a coisa fluir de forma tão orgânica.

Em nossos espaços de criação no Parque das Tribos, depois de contar as histórias proponho que imitemos as personagens, as ações dessas personagens, que performemos alguns momentos da história, que alguém conte, ou, reproduza a história a partir de suas percepções.

20 Já que os conceitos de arte e cultura são discutidos nesses contextos ameríndios a partir do olhar de nossa cultura ocidental, como nos mostram as antropólogas: Els Lagrou (2009) que vai discutir a questão da arte no mundo ameríndio e Manuela Carneiro da Cunha (2009) que falará sobre a questão da cultura. Ambas argumentando justamente que não há termos similares no mundo ameríndio, já que os indígenas não dissociam a arte da vida, tudo que é produzido na comunidade tem um significado para a existência daquele povo. 
Ainda sobre a questão do brincar relacionado à arte, em um dos encontros com Mepaeruna perguntei o que para ela era teatro, já que não existe tradução para a palavra teatro na língua Tikuna, nem existe teatro do modo como fazemos, ao passo que para dança (arüyü 'ü) e música (tchiga) existem palavras na língua. Os Tikuna não têm uma ideia de representação e personagem ${ }^{21}$, nem mesmo de ficção, como nós temos. Assim, Mepaeruna traduziu teatro como 'ẽãwaegü' (brincadeira).

O surpreendente disso, foi que quando estive pela primeira vez na aldeia Nossa Senhora de Nazaré, a título de curiosidade, havia feito essa mesma pergunta. Os Tikuna Marijane e Ondino (filha e pai), que me receberam em sua casa, conversaram muito comigo a respeito de como eles poderiam definir teatro e trouxeram a mesma tradução: ẽãwaegü (brincadeira). Mas disseram que era a brincadeira dos adultos, que pressupõe bagunçar com os outros, fazer piadas, gracejos, como um palhaço ou um bufão. Perguntei também, como poderíamos chamar um performer, um ator, que foi chamado de ngeẽcüraü, palhaço, relacionado a ideia de bagunceiro, doido, ou, daucüraüweẽü "aquele que gosta de bagunçar com as pessoas", ou, toügü (macacada), que vem de Toü, a máscara do macaco prego que aparece durante o ritual de iniciação feminina e representa uma figura cômica.

Porém, como disseram os Tikuna, a brincadeira da criança é diferente, é levada a sério por elas, que podem se "magoar" se sentem que são motivo de riso. É preciso muito respeito e cuidado no trato com as crianças, usar de delicadeza para adentrar no seu universo, sem forçar que falem, nem que participem das atividades. Algumas crianças são muito tímidas, não conseguem falar diante do coletivo, preferem ficar sozinhas, ou falar individualmente com o adulto que está conduzindo a prática.

O tempo de cada criança deve ser respeitado, criando-se um espaço que

\footnotetext{
${ }^{21}$ No ritual Tikuna de iniciação feminina Worecü ou A Festa da Moça Nova existem seres mascarados, mas não são considerados personagens ficcionais. Assim, o ritual pode se aproximar do campo das artes cênicas, da performance, onde temos elementos de teatralidade, de performatividade, com danças, músicas, máscaras, elementos visuais, em uma estrutura com início, meio e fim estipulados, mas não fixos, como uma improvisação, com alguns 'papéis' estabelecidos, que pressupõe ações específicas, repleto de signos que são compreendidos pelos pertencentes aquele povo.
} 
inspire confiança para que ela aos poucos vá interagindo cada vez mais com o grupo. Mergulhar no universo infantil é respeitar o silêncio da criança, deixar que sejam protagonistas, que parta delas a iniciativa, mas sem ficar persuadindo com perguntas ou forçando sua participação nas atividades. Quem nos fala a respeito disso é Adriana Friedman (2015) em sua pesquisa sobre crianças em espaços distintos, principalmente no trabalho com comunidades (citadinas, quilombolas e indígenas). A antropóloga e educadora trata o espaço infantil como um lugar sagrado, dizendo que devemos nos curvar e pedir 'licença' para entrar nesse território, e que o protagonismo da criança pode se expressar a partir de diferentes linguagens:

Dar voz às crianças significa oportunizar tempos e espaços nos quais elas possam 'falar, dizer, expressar-se' de forma espontânea, por meio de suas linguagens verbais e não verbais, seus sentimentos, percepções, emoções, momentos, pensamentos. (Friedman, 2015, p. 40).

Pensando na ideia do espaço infantil como um território sagrado, desejávamos organizar nossos encontros como um 'ritual', em um processo com início, desenvolvimento e final que se repetisse em sua estrutura, mas que a cada encontro fosse único. Mepaeruna sugeriu que começássemos com uma música, cantando e dançando em roda, já que era algo que envolvia o coletivo, as crianças gostavam e participavam.

Estabelecemos que começaríamos nosso 'ritual' com uma roda: todos de mãos dadas, olhos fechados, prestando atenção na sua respiração, em seu corpo, escutando os sons que se manifestavam no espaço, sentindo a temperatura do ambiente, a textura, a temperatura e o toque das mãos dos colegas do lado, nos concentrando, nos conectando com nós mesmos, com os outros e com o espaço.

Em seguida, introduzíamos alguma canção que nos levava à dança. Quem sugeria as canções era Mepaeruna ou alguma das crianças, que deveria repeti-la até que todos conseguissem cantar juntos. Como acompanhamento de nossas canções e danças tínhamos flautas, chocalhos e tambores.

Nós criamos uma prática com o tambor para as crianças, misturando a experiência na aldeia aos ensinamentos da oficina de 'Música orgânica' com o 
músico amazonense Eliberto Barroncas, realizada no II Seminário da Região Norte: Educação, Arte e Intercultura em setembro de 2018.

Eliberto Barroncas traz sua vivência com os indígenas e fala sobre a circularidade do tambor relacionada à circularidade da roda e às danças circulares em sentido anti-horário para que aconteça o fluxo de energia, propondo uma metodologia que se desenvolve em diferentes etapas até chegarmos a tocar o tambor.

Primeiro, experimentamos o som do tambor batendo com as palmas da mão, assim, dependendo de como batíamos, produzíamos o som grave (mão em concha) e o som agudo (pontas dos dedos na palma da mão). Segundo, fazíamos a batida em quatro tempos com os pés, caminhando pelo espaço. Terceiro, experimentávamos a batida do pé ao mesmo tempo em que tocávamos um instrumento (chocalho, flauta, tambor). Quarto, introduzíamos o canto. Por fim, dançamos, cantamos e tocamos nessa roda em sentido anti-horário que girava no espaço da sala.

Seguindo esse caminho trabalhamos com as crianças. Mas, antes de formarmos a roda coletiva sugerimos que cada uma experimentasse tocar os diferentes instrumentos individualmente, e na sequência, os reproduzissem com o seu corpo, fazendo a percussão a partir de diferentes formas de tocar o próprio corpo, ou com a voz, pensando que a voz é manifestação do corpo, como nos fala Paul Zumthor (2002).

Com essa proposição buscamos aguçar a percepção das crianças para os sons produzidos pelos instrumentos, para que então experimentassem em pequenos grupos compor ritmos, pois percebemos que com todos juntos era mais difícil controlar o caos sonoro que essa experiência evocava, já em grupos menores era mais fácil de orquestrar e fazer com que se percebessem enquanto coletivo. Quando já estavam melhor afinados é que partíamos para a roda com todos juntos. Depois, de 'aquecidos' e 'entrosados', abríamos nosso pequeno tapete verde no chão, que nos ajudava a concentrar o grupo no espaço e começávamos a contação de histórias, com a improvisação dela na sequência. 
Ao final das atividades, entregávamos folhas de ofício, giz de cera e lápis de cor para as crianças desenharem - que elas haviam pedido desde o primeiro encontro - com a proposta de manifestarem nos desenhos o que foi mais significativo das práticas. Todas ficavam à vontade em desenhar e podíamos ver como se expressavam as que eram mais tímidas. Fechávamos com o compartilhamento do lanche e nos despedíamos.

E assim era a estrutura do nosso 'ritual' semanal no Parque das Tribos: início, meio e fim definidos, como um roteiro, uma partitura, mas que a cada encontro nos propiciava uma nova experiência.

Nosso coletivo estava constantemente conversando, refletindo e buscando referências que nos ajudassem na prática, pensando em ações que conseguissem envolver de forma significativa as crianças. Entramos até em alguns embates, como, por exemplo, quando observamos que enquanto Mepaeruna contava uma história muitas crianças estavam dispersas, querendo pegar os bonecos, mexer nos objetos que havíamos levado, algumas viram o lanche e desde o começo só perguntavam dele.

Essa atitude de interesse pelo lanche desde o início aconteceu em outros encontros e fez com que uma das estudantes da UEA questionasse o momento do lanche, pois ela sentia que muitos só estavam interessados nele. Particularmente, acho normal as crianças, principalmente as menores, esperarem ansiosas o momento do lanche, não acho que participavam das atividades somente por isso e mesmo que fosse não vejo problema, não atrapalhavam, realizavam as proposições com tranquilidade e podiam sair quando quisessem, já que estavam do lado de suas casas e o portão do Espaço Cultural Uka Umbuesara Wakenai Anumarehit ficava aberto, além disso, não eram "obrigadas" a permanecer como se sentem, muitas vezes, em uma aula formal. Penso que abrindo mão desse momento a turma não iria mudar, pois sempre chegava gente nova, alguns ficavam um tempo sem vir, depois voltavam, e o lanche não era nada de extraordinário.

Reitero que o espaço de descontração propiciado pela hora do lanche é uma 
oportunidade para conversar e conhecer melhor as mães e as crianças. Mepaeruna também disse que não deveríamos deixar o momento de compartilhamento do alimento fora de nossas atividades. O dia em que experimentamos não levar o lanche, não fez com que as crianças fossem embora ou não voltassem, mas senti um vazio ao retirarmos esse momento tão descontraído de nossa prática, foi como se o desfecho do dia não tivesse acontecido.

Abaixo algumas fotos de alguns dos momentos de nosso 'ritual', não do mesmo dia, nem em ordem cronológica:

Figura 4 - Começo - Roda inicial todos de mãos dadas, momento de concentração. Espaço Cultural Uka Umbuesara Wakenai Anumarehit. Parque das Tribos, Tarumã, Manaus (AM)

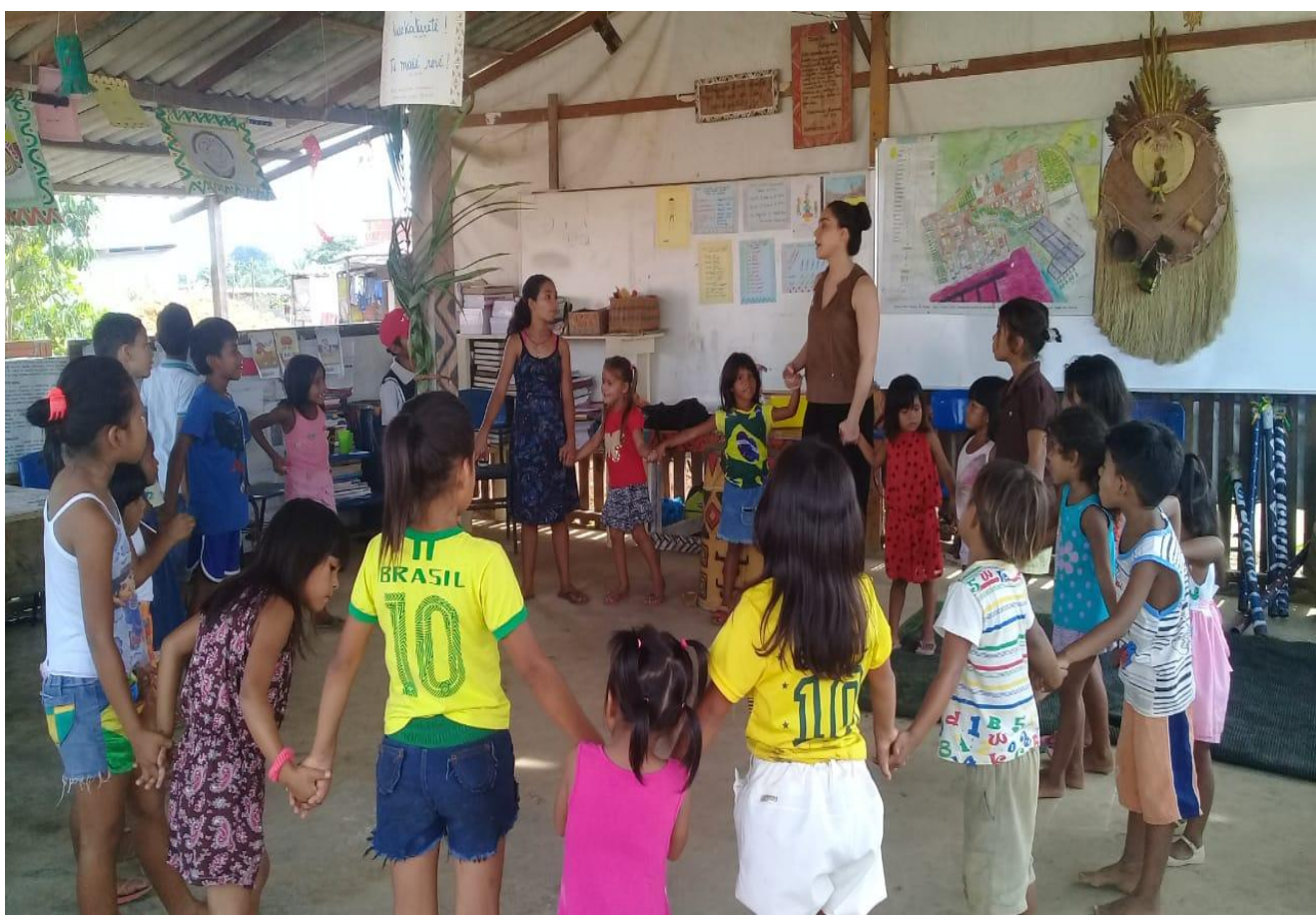

Foto: Arquivo pessoal da pesquisadora, 09 out. 2018 
Figura 5 - Desenvolvimento - Canto e dança com o tambor. Espaço Cultural Uka Umbuesara Wakenai Anumarehit, Parque das Tribos, Tarumã, Manaus (AM)

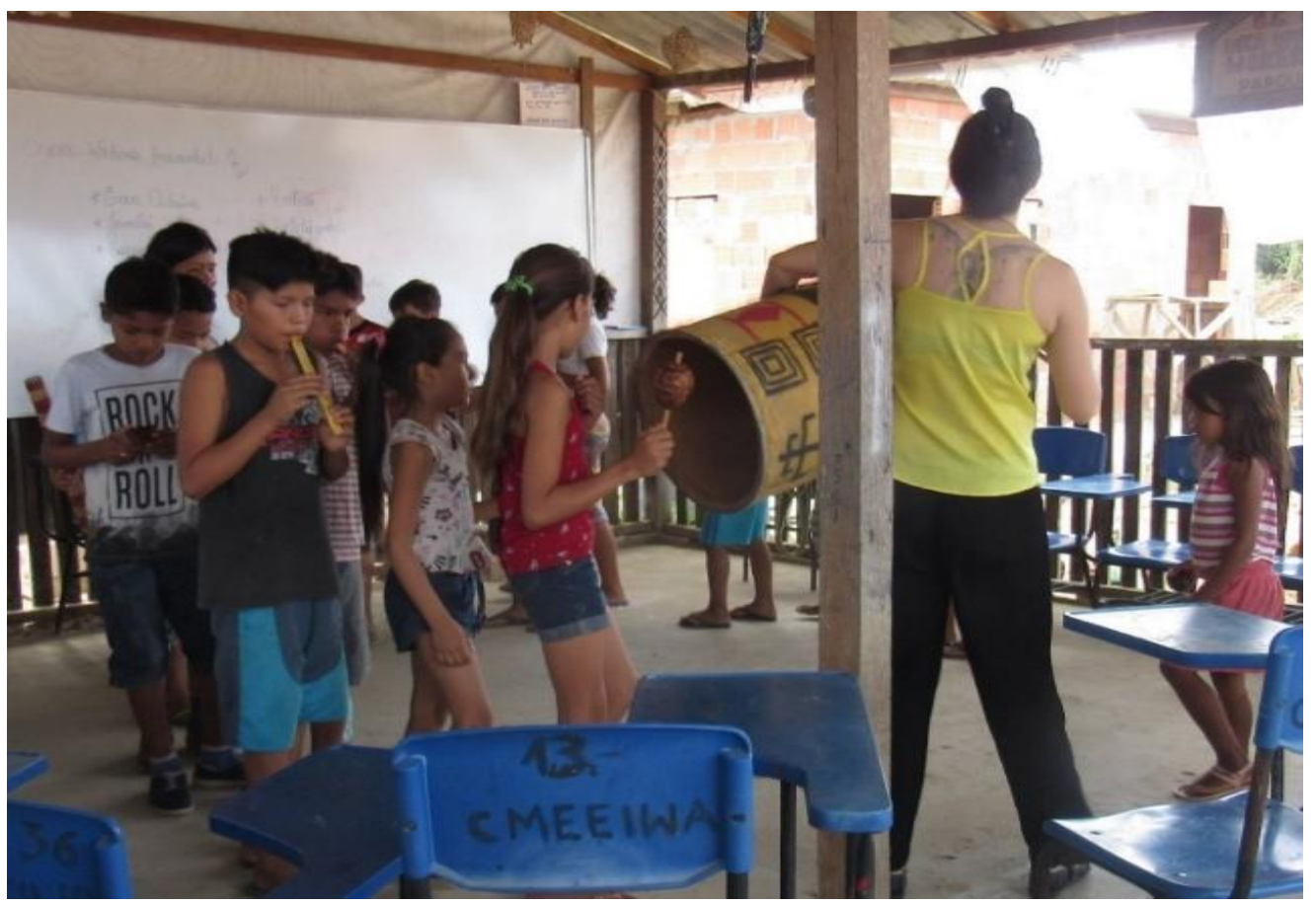

Foto: arquivo pessoal da pesquisadora, 20 set. 2018

Figura 6 - Atividade principal. Primeiro momento: apreciando a história. Espaço Cultural Uka Umbuesara Wakenai Anumarehit, Parque das Tribos, Tarumã, Manaus (AM)

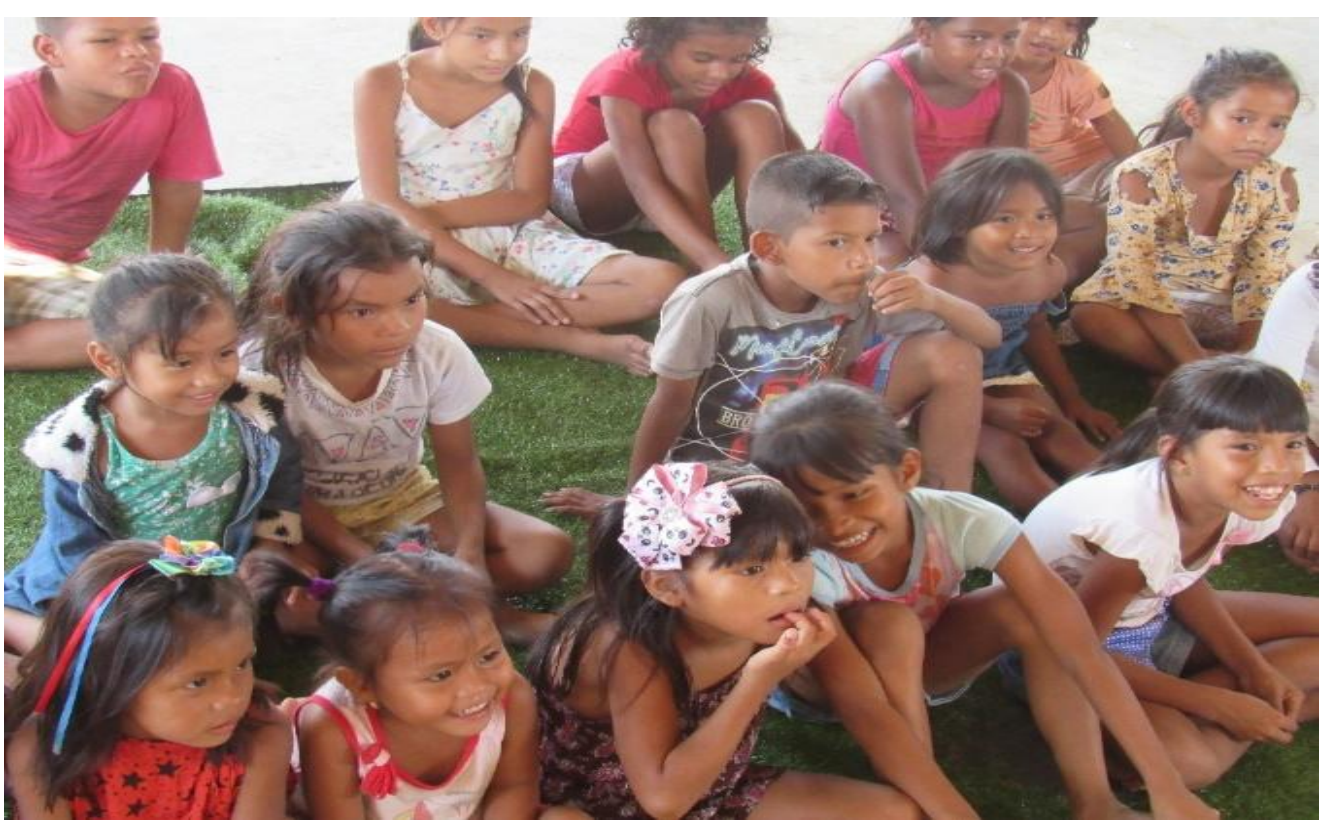

Foto: arquivo pessoal da pesquisadora, 25 out. 2018 
Figura 7 - Atividade principal. Segundo momento: performando a história. Espaço Cultural Uka Umbuesara Wakenai Anumarehit, Parque das Tribos, Tarumã, Manaus (AM)

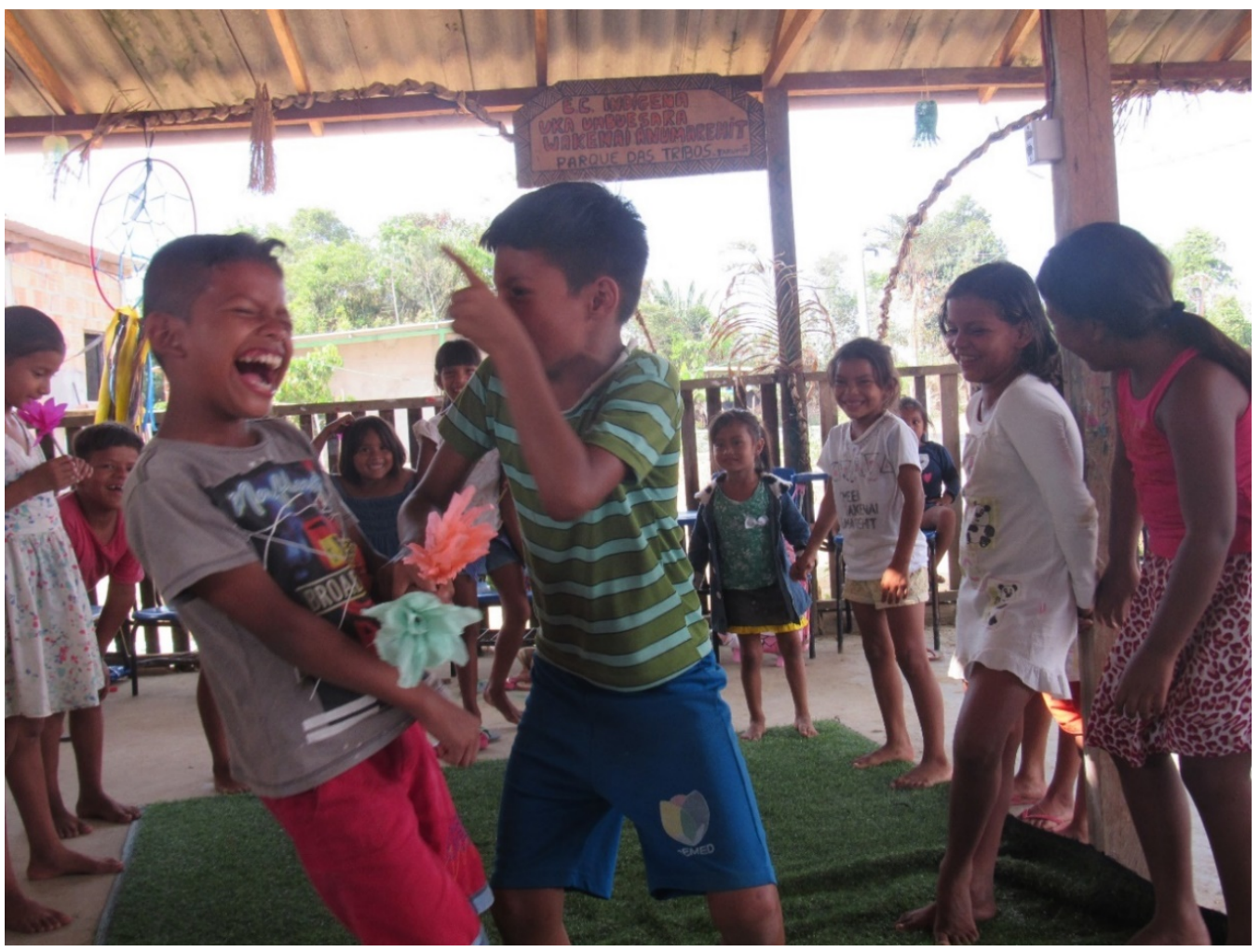

Foto: arquivo pessoal da pesquisadora, 25 out. 2018

Figuras 8 e 9 - Atividade principal: Aula de jenipapo: Mepaeruna ralando o jenipapo enquanto conta a história da origem dos grafismos. Depois espremendo no tecido o jenipapo ralado para tirar seu sumo. Espaço Cultural Uka Umbuesara Wakenai Anumarehit, Parque das Tribos, Tarumã, Manaus (AM)
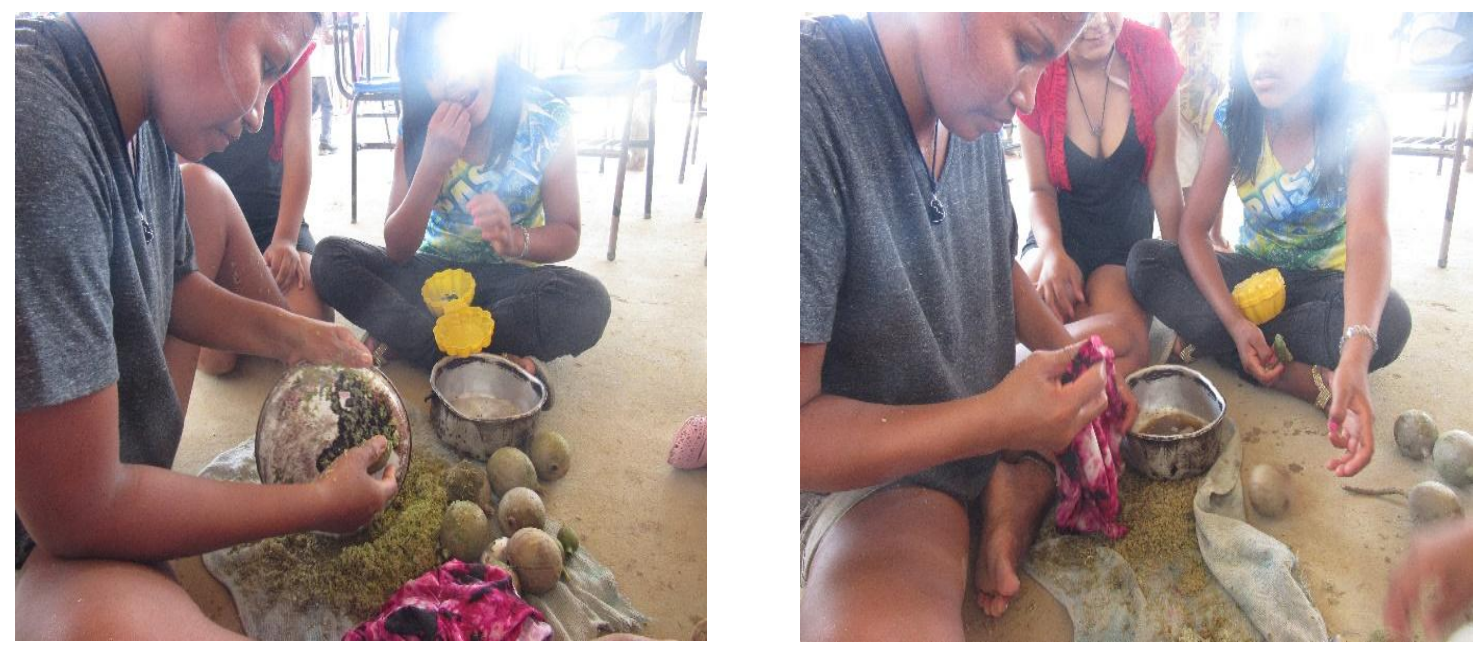

Foto: arquivo pessoal da pesquisadora, 29 ago. 2018 
Figura 10 - Mepaeruna fervendo o sumo do jenipapo. Figura 11 - Jenipapo esfriando para ser usado como pintura corporal. Espaço Cultural Uka Umbuesara Wakenai Anumarehit, Parque das Tribos, Tarumã, Manaus (AM)
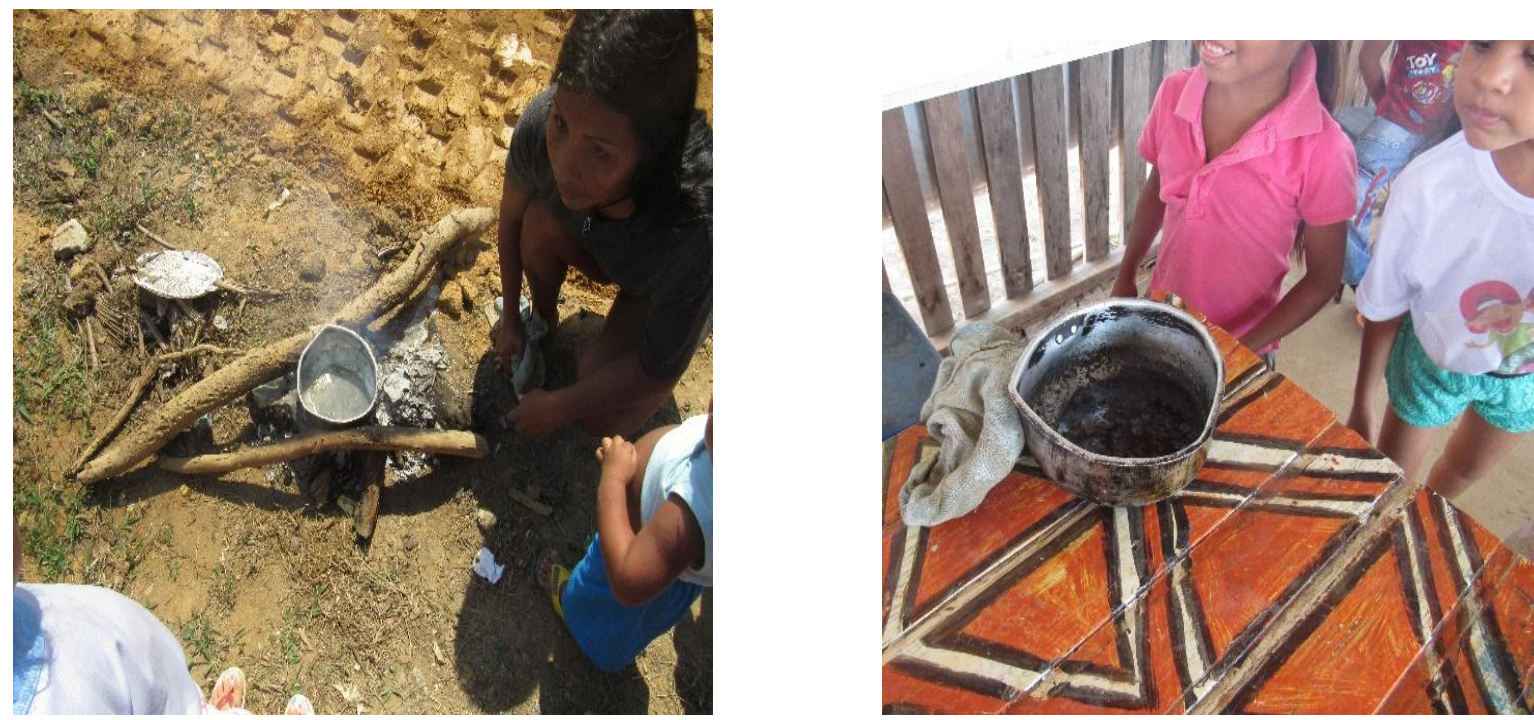

Foto: arquivo pessoal da pesquisadora, 28 ago. 2018

Figura 12 - Mepaeruna desenhando grafismo Tikuna de Tambor com sumo de jenipapo. Espaço Cultural Uka Umbuesara Wakenai Anumarehit, Parque das Tribos, Tarumã, Manaus, (AM)

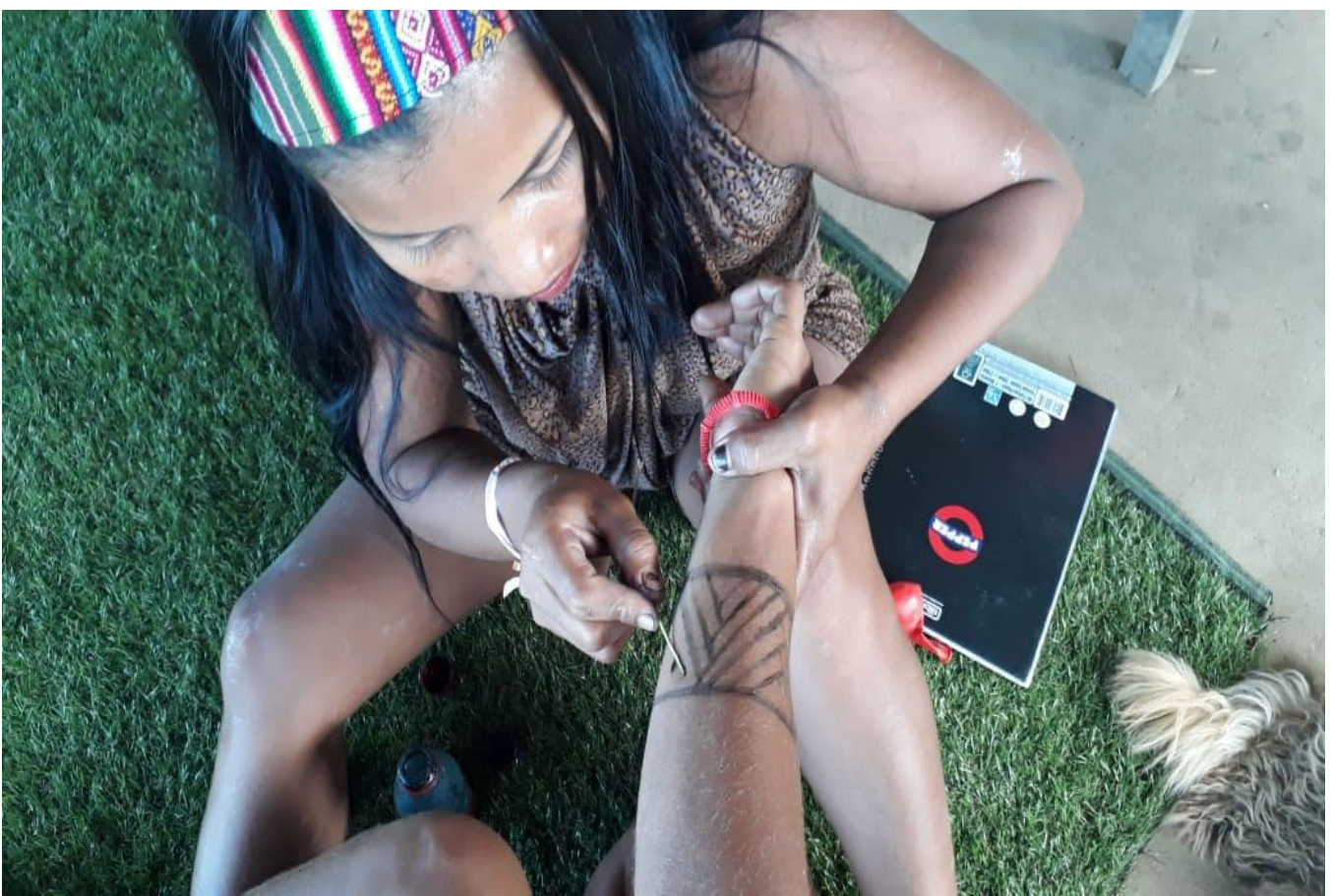

Foto: arquivo pessoal da pesquisadora, 25 out. 2018 
Figuras 13 e 14 - Finalização. Fechando com as impressões das práticas através dos desenhos. Espaço Cultural Uka Umbuesara Wakenai Anumarehit, Parque das Tribos, Tarumã, Manaus (AM)
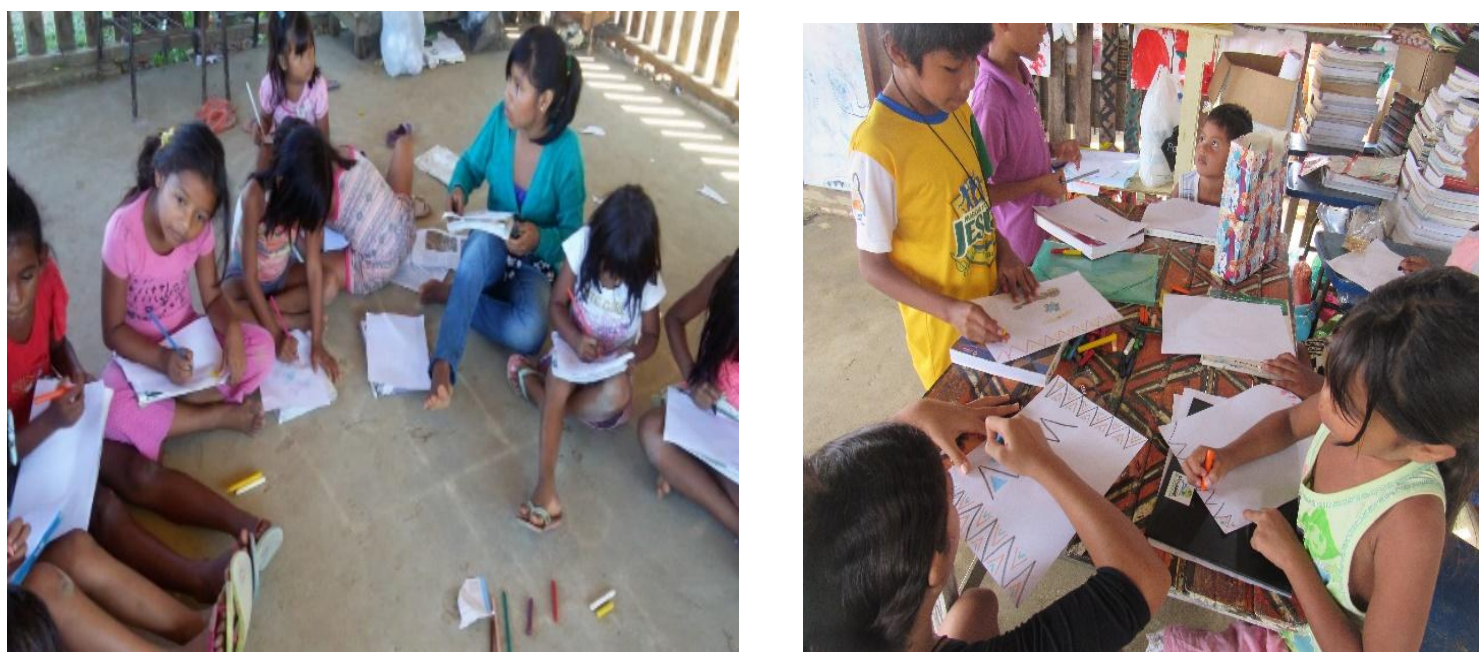

Foto: arquivo pessoal da pesquisadora, 15 jun. 2018

Figura 15 - Finalização - vamos lavar as mãos para lanchar? Figura 16 - Lanchando, nesse dia pipoca. Espaço Cultural Uka Umbuesara Wakenai Anumarehit, Parque das Tribos, Tarumã, Manaus (AM)
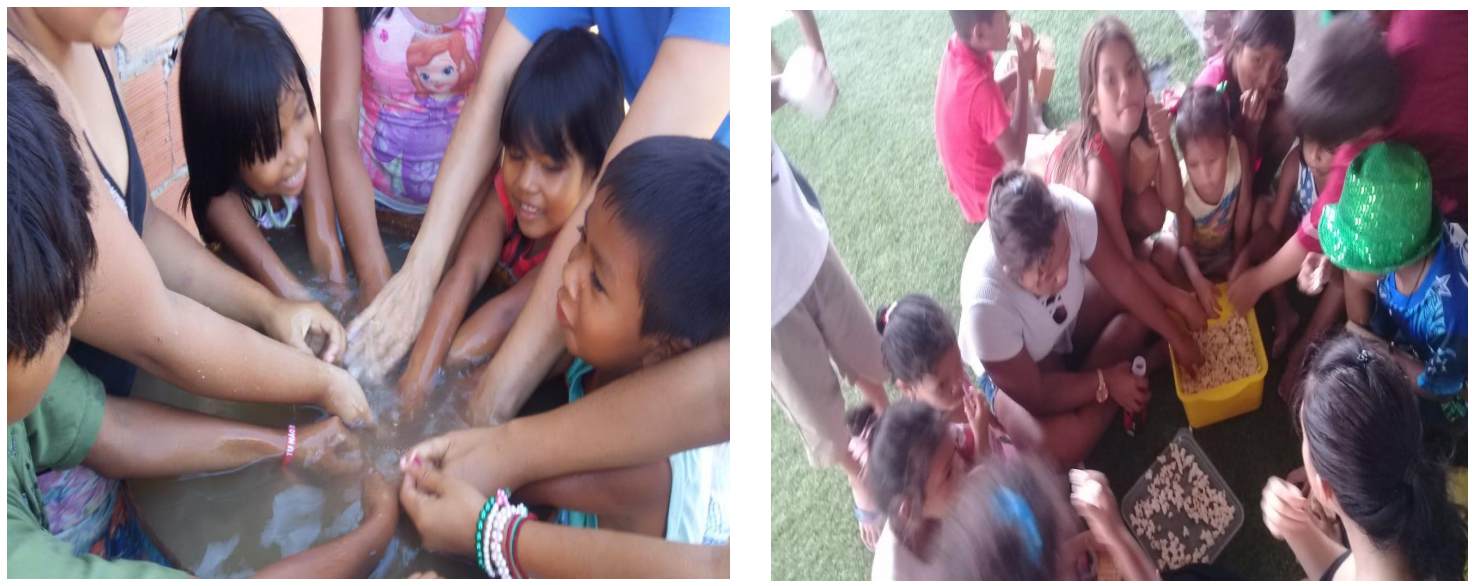

Foto: arquivo pessoal da pesquisadora, 30 jul. 2018

A minha vivência no Parque das Tribos foi uma experiência criativa, colorida, rica, intuitiva, inovadora e feliz. A maneira de conhecer e experimentar a proposta de uma nova pedagogia dentro das escolas indígenas contribuem muito para entendermos a metodologia desses novos centros de ensino, que pensam o mundo de forma integrada, mente, corpo e espírito. Essa forma tem tudo a ver com a nossa região amazônica, seu patrimônio imaterial e ambiental, a cosmologia dos povos da floresta; e o teatro não poderia ficar de fora disso, pois contribui muito como área do conhecimento para que essa identidade cultural seja formada desde os pequenos até o ensino médio. Durante as nossas 
visitas ao Parque das Tribos planejávamos as aulas utilizando como metodologia o teatro de formas animadas, estabelecendo logo um contato direto com o nosso público alvo: as crianças do povo Tikuna, tendo Mepaeruna, uma artista Tikuna, com uma imensa sabedoria sobre seu povo, como nossa mestra na condução e no termômetro de nossas atividades. Inicialmente, as crianças ficaram fascinadas pelos bonecos e também interessadas pela narrativa das histórias que contávamos, quando interpretávamos os diferentes personagens das histórias e lendas indígenas mais conhecidas por nossa sociedade urbana. Depois, num segundo momento, começaram a entrar no jogo de encenar as lendas Tikuna que formam a cultura de seu povo, cheia de cantos, magia e personagens mitológicos. As mães que frequentavam as aulas sempre ajudavam a lembrar os principais cantos e histórias Tikuna dançando ao som dos instrumentos que trazíamos e que eram experimentados pelas crianças. Posso dizer que mesmo essa comunidade indígena estando passando por um grande processo de urbanização, as famílias que moram estão ligadas as suas raízes, buscam manter viva a chama de seus parentes, de seus ancestrais. Eu como artista e arte-educadora não vejo outro caminho que não seja pela educação, por uma matriz pedagógica diferenciada nas escolas que vamos preservar o que temos de mais importante que é o ser humano vivendo em equilíbrio consigo, com o outro e com a natureza. (Depoimento de Vanessa Pimentel, atriz amazonense, estudante do curso de licenciatura em Teatro da UEA, participou de toda a fase do projeto com o grupo Tikuna de Mepaeruna).

\section{Por estradas sinuosas - novos instrumentos de aprendizado}

Além dessas experiências poéticas que seguiam uma mesma linha de prática, experimentamos em um de nossos últimos encontros, antes das férias, trabalhar com a tecnologia, já que era perceptível o interesse das crianças por esse universo. Propusemos que realizassem o que chamamos de um pequeno documentário, um vídeo curto, que elas iriam filmar usando uma câmera amadora e celulares. O tema de nosso documentário partiu da seguinte pergunta: "qual o lugar do Parque das Tribos que vocês mais gostam?”. Assim, saímos da "escolinha” (como as crianças chamam o Espaço Cultural Uka Umbuesara Wakenai Anumarehit) e fomos até o terreno eleito por unanimidade como o melhor lugar do Parque das Tribos: o campo de futebol.

Esse dia foi uma aventura, um dos mais divertidos, pois para chegar até o campo de futebol precisávamos passar por alguns espaços inusitados: ladeiras íngremes e igarapés cercados por mato e barro. As crianças estavam bastante 
entusiasmadas por estarem na liderança do processo, elas guiavam a caminhada e faziam a filmagem, eu e uma das estudantes participante do projeto ajudávamos os menores e acompanhávamos os maiores que comandavam o grupo. Para seguirmos até o campo de futebol nosso lema era: "ninguém solta a mão de ninguém."

Figura 17 - Aprendendo a usar a máquina para filmar

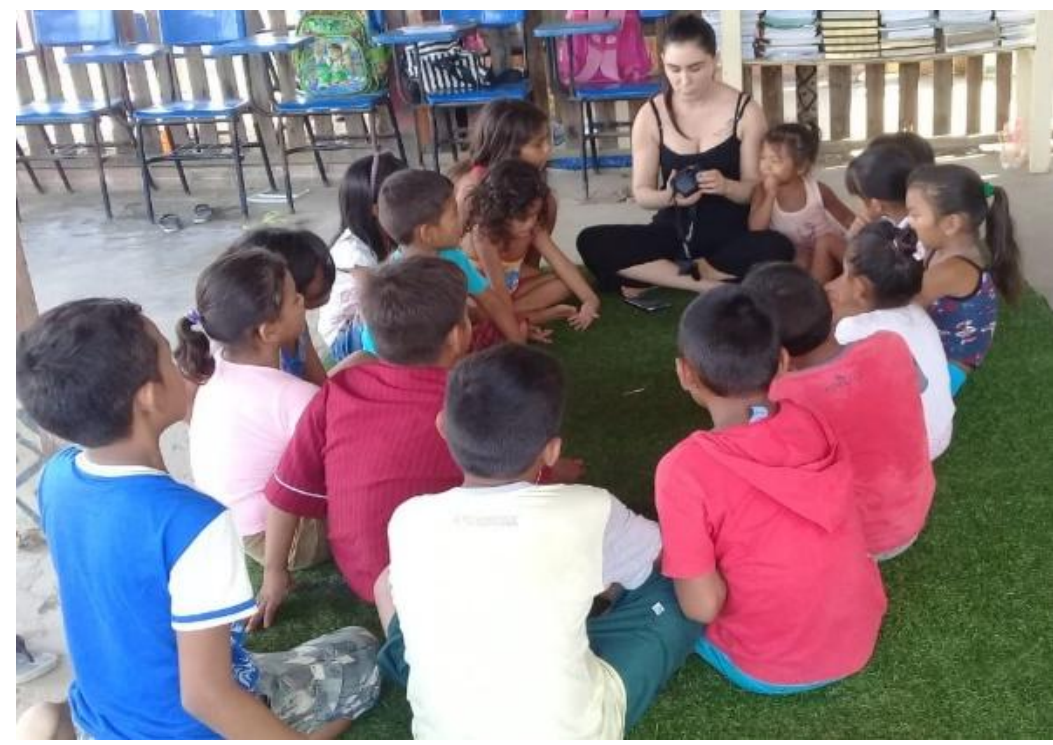

Foto: arquivo pessoal da pesquisadora, 07 dez. 2018

Figura 18 - As crianças nos levando para o campo de futebol. Espaço Cultural Uka Umbuesara Wakenai Anumarehit, Parque das Tribos, Tarumã, Manaus (AM)

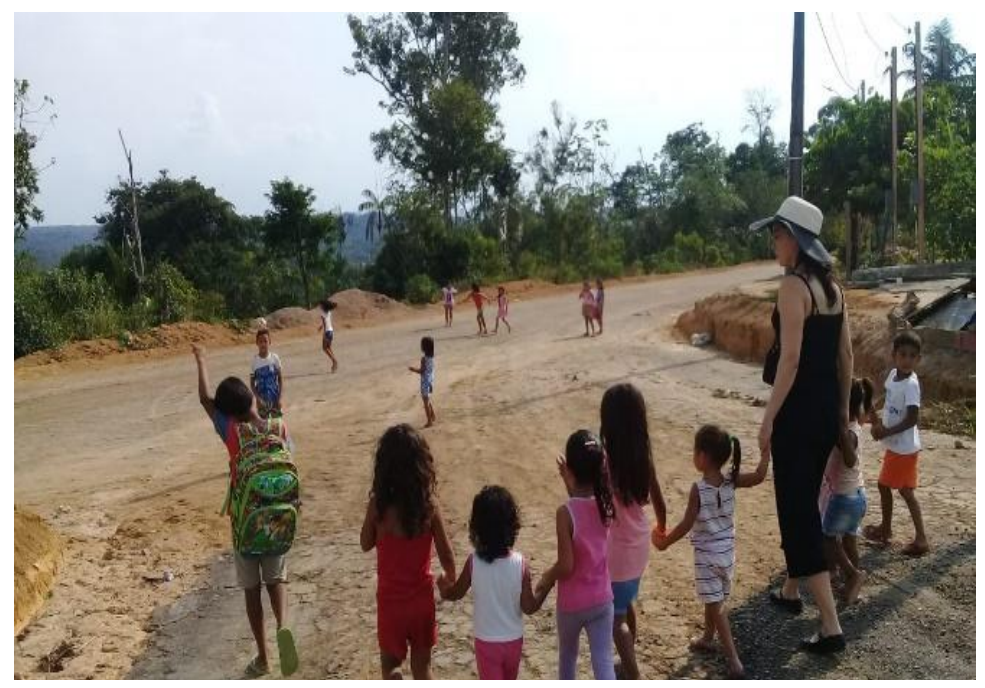

Foto: arquivo pessoal da pesquisadora, 07 dez. 2018 
Figura 19 - Descendo a mata para chegar do outro lado do Parque das Tribos onde encontraríamos o campo de futebol. Figura 20 - O campo de futebol. Parque das Tribos, Tarumã, Manaus (AM)
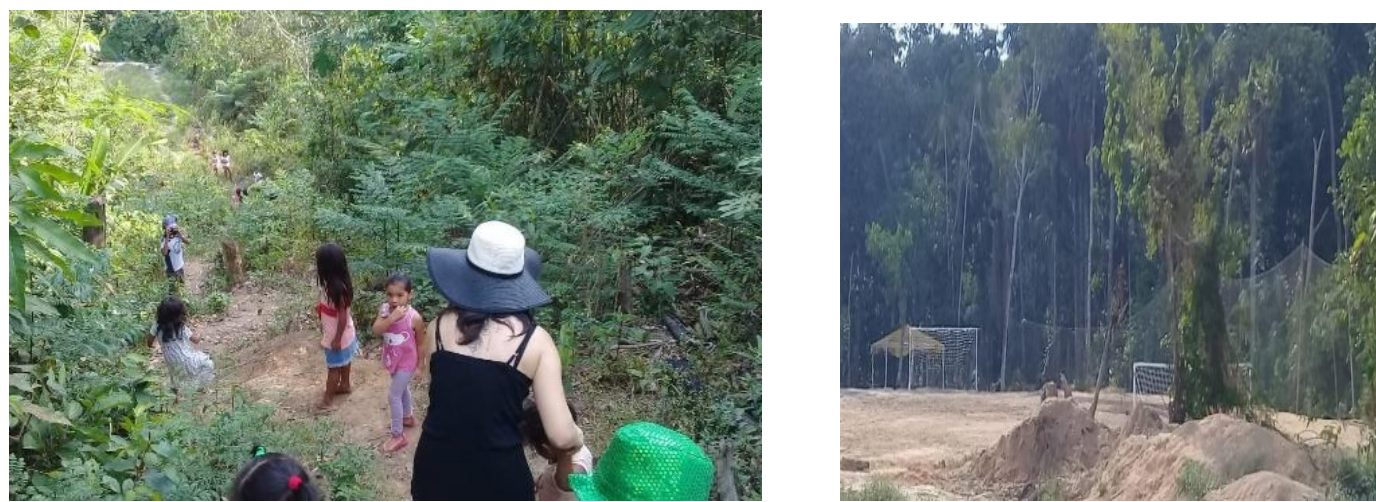

Foto: arquivo pessoal da pesquisadora, 07 dez. 2018

$\mathrm{Na}$ semana seguinte assistimos a filmagem e conversamos sobre ela. As crianças deram muitas risadas ao se ver no vídeo e fizeram uma análise crítica sobre cada uma que filmou, refletindo o porquê de algumas imagens terem ficado melhores do que as outras, segundo elas, quem estava sendo "gaiato"22 não filmou “direito”, pois ficava rindo e 'bagunçando' com os outros, quem utilizou uma linguagem mais "jornalística" - digamos - narrando os acontecimentos, elas consideraram que se saiu melhor.

Figura 21 - As crianças assistindo sua filmagem. Espaço Cultural Uka Umbuesara Wakenai Anumarehit, Parque das Tribos, Tarumã, Manaus (AM)

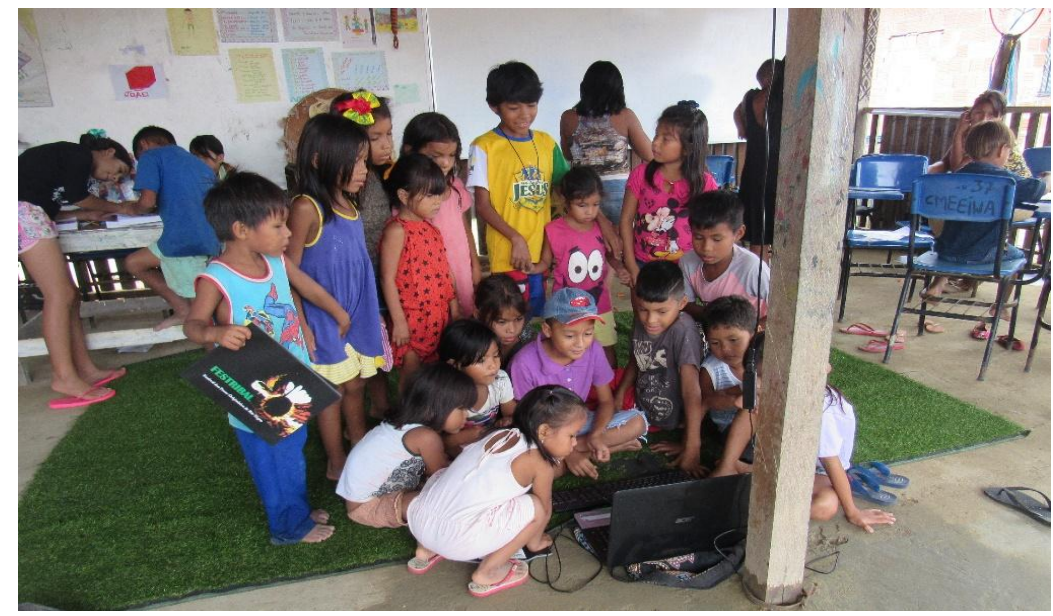

Foto: arquivo pessoal da pesquisadora, 14 dez. 2018

${ }^{22}$ Os indígenas com quem convivo usam muito essa palavra para se referir as pessoas piadistas, brincalhonas. 
Outra atividade significativa que realizamos com as crianças no ano de 2018, foi levá-las ao Teatro Amazonas no 13ํ Festival de Teatro da Amazônia para assistir à peça de clowns: A excêntrica família de clowns, da Companhia Língua de Trapo de Manaus, dirigida por Hely Pinto, bonequeiro amazonense, que quando cheguei em Manaus me ensinou uma das técnicas de confecção de bonecos. Considero significativa essa experiência, pois as crianças saem da comunidade e podem se relacionar com outras pessoas em outros espaços, e percebo o quanto se sentem valorizadas com isso. Conseguimos o transporte da UEA para a realização dessa atividade, um trajeto que leva do Parque das Tribos ao Teatro Amazonas mais de uma hora de ônibus.

No final as crianças conversaram com os atores da peça, conheceram o camarim, depois falamos sobre a experiência, elas gostaram de assistir, acharam divertido, não sentiram medo dos palhaços e a maioria disse que gostaria de ir mais vezes ao teatro. Com o projeto sempre buscamos essas trocas de ir até a comunidade e levar a comunidade até a universidade, ao teatro e outros espaços que possam estabelecer encontros com trocas produtivas.

O ano de 2019 foi o ano em que estive de licença para terminar minha tese de doutorado em São Paulo, no entanto o projeto seguiu sendo desenvolvido pelos estudantes do Curso de Teatro da UEA, e quando retornei no início de 2020 voltamos com as atividades, no entanto, a pandemia do corona vírus impediu que seguíssemos, estamos parados em relação ao projeto, mas desenvolvendo atividades de arrecadação de dinheiro, mantimentos, remédios, produtos de limpeza e máscaras faciais para os moradores no Parque das Tribos que enfrentam muitas dificuldades diante dessa realidade a qual nos encontramos.

\section{Referências}

CUNHA, Manuela Carneiro da. Cultura com aspas e outros ensaios. São Paulo: Cosacnaify, 2009.

FRIEDMAN, Adriana. O olhar antropológico por dentro da infância. Território do brincar: diálogo com escolas. Renata Meirelles (org.). São Paulo: Instituto Alana, 
2015.

LAGROU, Els. A fluidez da forma: arte, alteridade e agência em uma sociedade amazônica (Kaxinawa, Acre). Rio de Janeiro: Topbooks, 2007.

LAGROU, Els. Arte indigena no Brasil: agência, alteridade e relação. Editor: Fernando Pedro da Silva; Coordenação: Fernando Pedro da Silva e Marília Andrés Ribeiro; Orientações Pedagógicas: Lucia Gouvêa Pimentel e William Resende Quintal. Belo Horizonte: Editora C / Arte, 2009.

PETIT, Michèle. Ler o mundo: Experiências de transmissão cultural nos dias de hoje. São Paulo: Editora 34, 2019.

PILETTI, Nelson; ROSSATO, Geovanio; ROSSATO, Solange Marques. Psicologia do desenvolvimento. São Paulo: Contexto, 2014.

PROFESSORES TIKUNA BILÍNGUES (Org). O Livro das Árvores. Impressão: Gráfica e editora Brasil Ltda. Benjamin Constant, AM, Brasil, 1998.

Recebido em: 05/06/2020

Aprovado em: 07/07/2020 